\title{
A „Politika az interneten” című tanulmánykötetről
}

A Kiss Balázs és Boda Zsolt által jegyzett „Politika az interneten” című könyv 2005-ben a Századvég kiadó gondozásában jelent meg. A kötet alapjául szolgáló kutatás szerzői közé tartozik a fentieken kívül Varga Barbara, Berta Kata és Szabó Gabriella is, akik jelentős részt vállaltak a mű elkészítésében. A jelen ismertetés a következőképpen épül fel: a mű vizsgálódásának tárgya, majd egyes fejezeteinek bemutatása után a szerző azokat a könyvből hiányzó kérdéseket szedi csokorba, amelyek arra figyelmeztetnek, hogy az új média eddig ismeretlen kihívások elé állította a politikatudományt.

Kulcsszavak: politika, e-kormányzat, tömegkommunikációs eszközök, politikatudomány, új média, internet

\section{Szerzői információ:}

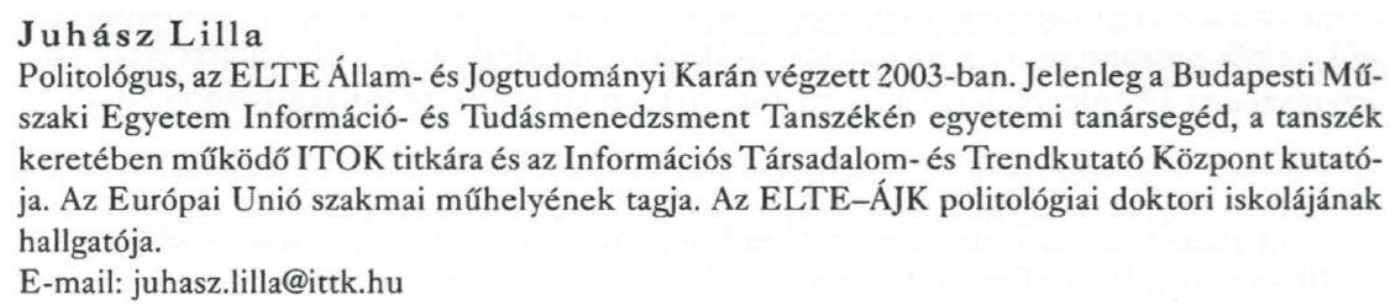
keretében múködô ITOK titkára és az Információs Társadalom- és Trendkutató Központ kutatója. Az Európai Unió szakmai múhelyének tagja. Az ELTE-ÁJK politológiai doktori iskolájának hallgatója.

E-mail: juhasz.lilla@ittk.hu

Így hivatkozzon erre a cikkre:

Juhász Lilla. „A „Politika az interneten” című tanulmánykötetről”.

Információs Társadalom VI, 1. szám (2006): 107-113.

A folyóiratban közölt müvek

a Creative Commons Nevezd meg! - Ne add el! - Így add tovább! 4.0

Nemzetközi Licenc feltételeinek megfelelően használhatók. 
Juhász Lilla

\section{A ,Politika az interneten” címú tanulmánykötetról}

A Kiss Balázs és Boda Zsolt által jegyzett Politika az interneten címú könyv 2005-ben a Századvég Kiadó gondozásában jelent meg. A kötet alapjául szolgáló kutatás szerzối közé tartozik továbbá Varga Barbara, Berta Kata és Szabó Gabriella is, akik jelentốs részt vállaltak a mú elkészítésében. A jelen ismertetés a következôképpen épül fel: a mú vizsgálódásának tárgya, majd egyes fejezeteinek bemutatása után azokat a könyvból hiányzó kérdéseket igyekszem csokorba szedni, amelyek arra figyelmeztetnek, hogy az új média eddig ismeretlen kihívások elé állította a politikatudományt.

A politika és az internet kapcsolatát taglaló könyv nagy erénye, hogy megszületett, a magyar politikatudományi szakirodalomban hézag- és hiánypótlónak tekinthetố. Egyszerre kísérli meg az elméleti megközelítések és a helyzet bemutatását, majd a hipotézisek és elófeltevések igazolását a tények és a tapasztalatok segítségével végzi el, a külföldi példák elemzése mellett fóként a magyar helyzetre fókuszálva. Problematikus azonban, hogy az elószó elolvasása után máris ambivalens érzés keríti hatalmába az olvasót. Míg a nagyra törố cím azt sugallja, hogy tudományos igényú alapmúvel állunk szemben, amely tagolt problématér segítségével tudatosítja és rendszerezi azokat a kihívásokat, amelyek elé az internet állította a politika világát, addig az elószó öt év kitartó kutatásának eredményeire, az alacsony internetpenetrációra hivatkozva a politikai kommunikáció és az internet viszonyára szúkíti a vizsgálódás tárgyát, és kizárólag az institucionalista megközelítés talaján állva tartja lehetségesnek tudomány-rendszertanilag értelmezni és elemezni a politika igencsak komplex világát.

Zavartságunk azonban tovább fokozódik: a könyv fejezeteit szemügyre véve ugyanis azt látjuk, hogy újra a teljességre törekvés vágyától fútve már az internet és a politika terrénumainak metszéspontjaitól távol esố területek némelyike - például az e-kormányzat - is megmérettetik. A recenzens feladatát tovább nehezíti, hogy a tanulmánykötet egészét a cizellált és szofisztikált sokdimenziós vizsgálódás helyett dichotomikus megközelítésmód uralja: a kötet szerzối nem tudnak túllépni a technofiltechnofób tengely problematikáján, ami azonban kizárólag a Herceg és a Kalmár ${ }^{1}$ autoriter, illetve demokratikus viszonyának a szempontjából tekinthetố relevánsnak. A kötet - kimondatlanul ugyan - a technooptimizmus és a technofób szélsőségnek bélyegzett szakirodalmi források közötti egyensúlyt és harmóniát kínáló megközelítés, az empirizmussal igazolt technorealizmus hírnökeként tekint magára.

A kötet az elméleti alapvetések mellett megelégszik a politikai tartalmak internetre költöztetésének illusztrálásával, technikai szempontból ugyanis az elektronikus levelezésból és grafikus felületból nyilvánosan megismerhetố politikai kommuni-

\footnotetext{
${ }^{1}$ Jody Jensen - Miszlivetz Ferenc (2005): Globális civil társadalom: a másképpen gondolkodás diskurzusától a világbanki zsargonig. Civil Szemle, II. évfolyam, 4. szám.
} 
kációt veszi górcsố alá, három szereplő́csoport - a megszilárdult politikai intézmények, a bevett tömegkommunikációs intézmények és az állampolgárok-internetes jelenlétét mutatva be. A mú a posztmodernitást tekinti átfogó kontextusnak, mivel szerzói úgy látják, hogy a politikatudományi internetparadigma még nem ment végig a diszciplínává válás útján. Az offline médiakutatásban alkalmazott szokásos módszereket az online környezetre is érvényesnek tekintik, mivel többségük tagadja az internet unikális jellegét, s azt pusztán egynek tekintik a kommunikációs eszközök sorában. Ugyanakkor az internetdiszciplína emancipációs küzdelméért harcoló valamennyi elméletet negligálják, a deduktív jelleg, illetve a ,jövendốmondás" dehonesztáló billogát rájuk sütve és a tudományosság terrénumán kívülre számúzve azokat.

A teljesség igénye ugyanakkor megköveteli, hogy a recenzens is állást foglaljon és kifejtse, miként vélekedik az internet mint új kommunikációs médium szerepéról. Véleményem szerint az internet forradalmi hatásának hullámai azonban nem az online, hanem sokkal inkább az offline világon söpör végig. Egy olyan társadalom, ahol a munkavállalás egyre nagyobb részét a távmunka teszi ki, és a fiatalok egyre nagyobb hányada egyetemi végzettségre tesz szert, többé nem írható le az ipari társadalom kategóriáival, fogalmi rendszerével. A társadalom mélystruktúrájában zajló változások valamennyi alrendszer, így a politika terrénumát is újjászervezik. Az internetparadigma már önálló tudományterületként identifikálta magát, ami szükségszerúen a politikatudományt is újfajta diskurzusok lefolytatására készteti.

\section{Kiss Balázs: Az internet politikatudományi diskurzusai}

A fejezet arra tesz kísérletet, hogy elméleti oldalról értékelje, milyen kihívások elé állította az internet megjelenése és terjedése a politikatudományt. Szerzóje az értelmiségi irodalom jövendölései, a szakirodalomban feltett kérdések és az úgynevezett „kihívásirodalom” alapján veszi górcső alá, hogy a politika tudományának tárgya, elnevezése és érvényességi köre megváltozott-e az új médium hatására. Az értelmiségi jövendöléseket az optimista/pesszimista dichotómia köré rendezi. Míg az internetnek világmegváltó szerepet tulajdonító optimista gondolatmenetek körébe a közvetlen demokrácia, az elektronikus agóra, a transzparenciát elősegítố interaktivitás megvalósulását váró elméleteket sorolja, addig véleménye szerint a pesszimista jövókép hírnökei a képviseleti elv sérülésének, az információs túlterheltségnek, a totális megfigyelés orwelli víziójának megvalósulásától tartanak.

Az értelmiségi jövendölések elméleti hátországának Harold Innis, McLuhan és Manuel Castells munkásságát tekinti, ezeket a kutatókat nem az információs társadalom panteonjának nagyjaiként szerepeltetve, hanem pejoratíve ,jövendőmondóként”, a futurológia híveiként állítva be óket. Az internetról szóló politikatudományi szakirodalom kapcsán Roman Gerodimosnak a bináris logikán, illetve a „technológiai determinizmus versus megerősítés" paradigmán alapuló téziseinek bemutatására helyezi a fố hangsúlyt. A technológiai determinizmus fogalomkörébe a társadalomnak az uralkodó médiumok által történó interpretálását, valamint a politika terrénumának a radikális átalakulását és a médiumok újjászervezôdését független változónak tekintố gondolatmeneteket sorolja. A "megerôsítés" paradigmája a skála ellentétes oldalán foglal helyet: 
ennek az a lényege, hogy az új médiumok a hatalmi viszonyok megerôsítését szolgálják. Kiss Balázs úgy látja, hogy a technikai vagy technológiai determinizmus szemlélete meggyöngült, a vizsgálatok hátterében álló világkép fragmentálódik, és ezzel szoros összefüggésben az internetet unikális médiumnak tekintő felfogás végleges háttérbe szorulását vallja.

A „kihívásirodalommal” foglalkozó részben azokat a politikatudományi diskurzusokat veszi szemügyre, amelyek - bár a par excellence politikát nem késztetik öndefiníciós kísérletekre - bizonyos fogalmak átértékelődését elindították. Idesorolja a politikai részvétel, a közösség, a kommunikáció és a tömegkommunikáció, valamint a szabadság és a politika fogalmaival operáló terminológiák változásait.

\section{Kiss Balázs - Boda Zsolt: Pártok és kampányok az interneten}

Ebben a fejezetben - a könyv tárgyának megragadásához választott institucionalizmus módszertanának szellemében - a pártok és a választási kampányok internetes jelenléte mérettetik meg. A vizsgálódás tárgya kettôs: egyrészt annak feltérképezésére irányul, hogy a pártok miként használják az új kommunikációs médiumot, másrészt pedig arra, hogy az elektronikus kommunikáció vajon hatással van-e a pártok szervezeti felépítésére és „,a társadalomba való beágyazódottságára”.

A virtuális kampányok kérdéskörének vizsgálatához a szerzók Davis elméletét veszik alapul, amely a kampányok tekintetében az alábbi hat fớ funkciót tulajdonítja az internetnek: szimbolikus funkció, információátadás, a közvélemény becsatornázása, interaktivitás, a szavazók megerôsítése és mobilizálása, valamint a támogatók és a pártok megszervezése. A választott modellel és az általuk ismertetett empirikus vizsgálati adatokkal az internetes politikai kommunikáció újabb korlátaira kívánnak rámutatni, valamint azt próbálják igazolni, hogy a politika világát nem forradalmasította a virtuális kampányok megjelenése. A hazai és külföldi példák alapján az internetes kampányok mintázatainak különbségeire figyelmeztetnek, de néhány általános érvényú trendet is kirajzolódni látnak. Ennek szellemében általános tendenciaként vélik felfedezni, hogy a pártok egyre nagyobb hangsúlyt helyeznek internetes kommunikációjuk tökéletesítésére. Ennek köszönhetốen az internetes kommunikáció kiegyenlítô szerepet játszhat a kis és nagy pártok között, hiszen alacsony költséggel is kivitelezhetô. A pártok internetes kommunikációjában a szimbolikus funkció és az információátadás tekinthetố a leginkább dominánsnak, míg az internetes kommunikáció mobilizációs hatása gyenge, bár a pártstruktúra átalakításában, a pártok és támogatóik közötti viszony alakításában szerepet játszhat.

A bemutatott gondolatmenet tesztelése végett - a nemzetközi tapasztalatok értékelését követôen - a 2002. évi magyar internetes politikai kampányt veszik górcsố alá a szerzốk. Összességében azt a képet látják kirajzolódni, hogy valamennyi párt él az internetes kommunikáció kínálta lehetőségekkel, de kevéssé használnak interaktivitást lehetôvé tevő alkalmazásokat. A kisebb pártok relatíve jobban élnek a virtuális kampány eszközeivel, az aktivitás terén pedig a baloldal tekinthetô igazán hatékonynak. 


\section{Kiss Balázs - Boda Zsolt: E-kormányzás}

Miként a bevezetóben már jeleztük, az e-kormányzat témaköre a politika és az internet metszéspontjaitól távol esố helyet foglal el. A nemzetközi arénában napjainkban új tendencia rajzolódik ki: a közigazgatásban nélkülözhetetlenné vált a hivatásos bürokrácia, ami nem a politika terrénuma többé, hanem a speciális szakértelemé. A közigazgatás szervezeti rendszerét - miként a szerzók maguk is jelzik - Magyarországon még erôs etatizáltság jellemzi, tehát bizonyos mértékig indokolt lehet az e-kormányzat témakörének bemutatása, ám a fejezet terjedelménél fogva mégis úgy érzem, hogy a kérdéskör tárgyalása a kötetben túldimenzionálttá vált.

A tanulmány az elektronikus kormányzással kapcsolatos politikának az amerikai és a brit modellre jellemzô felfogását és az ehhez kapcsolódó állampolgárképet mutatja be. Elméleti keretét Gloria Regonini definíciója adja meg, aki az elektronikus kormányzás három szintjét különíti el: a részlegek közötti adatcseréket biztosító e-közigazgatást, a szakpolitikák kialakításának a szintjét, valamint az állampolgárok és a kormányzati szervek közötti dialógust biztosító elektronikus demokrácia szintjét.

A szerzók az e-kormányzattal kapcsolatban azokat a kritikai kérdéseket feszegetik, melyek szerint az állampolgárok pusztán fogyasztónak minősülnek, az e-kormányzás pedig nem más, mint az üzleti életból átvett modell adaptációja, amelynek a segítségével a súlyos demokratikus deficittel küszködố állami szektor legitimálni képes saját múködését. Eben a megközelítésben a mérhetôséget, az indikatorológiát és az eredmények számszerúsíthetôvé tételét nem a szolgáltató állam kiépítése felé vezető útként, hanem a politikai propaganda eszközeként határozzák meg.

A bemutatott francia esettanulmány, majd a magyar e-kormányzati stratégia e-Kormányzat 2005 címú dokumentuma és az abban megfogalmazott fejlesztési program értékelése is ebben a kontextusban nyer értelmet: a felülról vezérelt stratégiai tervezés célja a hatékonyság, költségcsökkentés és a transzparencia álcája mögé rejtve olyan felmutatható eredmények keresése, amelyek a választások alkalmával szavazatokká transzformálhatók. A pragmatista és paternalista felfogást a szerzók szerint jól tükrözi az is, hogy a részvételi demokrácia és a konzultáció elemei rendre marginális szerepbe kerülnek, az állampolgár pedig kliensként jelenik meg, aki bizonyos szolgáltatások haszonélvezójévé válik, de semmiképpen sem lesz a kormányzati politika kialakításában helyet kapó, a politikai elittel egyenrangú szerepló.

A diagnózis - az e-kormányzással kapcsolatos kételyek - megfogalmazása után a szerzók nem késlekednek a terápiát kínáló megoldások bemutatásával sem. A fejlesztés útját Klaus Lenk és Roland Traunmüller munkája nyomán jelölik ki. Az e-kormányzati fejlesztési programoknak szerintük a front office jellegú folyamatok átalakítására, $s$ itt központi szervezóelvként a címzetteknek (az állampolgároknak) a középpontba állitására, az állampolgári igények mind szélesebb körú figyelembevételére, a back office folyamatok kapcsán pedig a folyamat-központúság megteremtésére kell irányulniuk. Fontos cél továbbá a taylori üzemszervezési elvek kritikátlan adaptációjának elvetése, a kooperációs perspektiva alkalmazása, a policy network, azaz a szakpolitikai hálózat kialakítása, az együttmúködés egyre szélesebb alapokra történő helyezése a közigazgatás intézményrendszerén belül és az állampolgárokkal történó viszonyban egyaránt, valamint a tudásperspektíva, a hallgatólagos (tacit) tudás explicit tudássá transzformálása. 


\section{Szabó Gabriella: Internetes tömegkommunikáció}

A fejezet az online tömegkommunikáció helyét keresi a jelenlegi tudományos diskurzusokon belül. A bemutatott szakirodalom alapján a szerzó arra a következtetésre jut, hogy a kommunikációkutatás többé nem hagyhatja figyelmen kívül az új médiumot. Az elméleti alapok ismertetésén kívül újfajta megközelítéseket is bemutat, és a 2004. évi európai parlamenti választásokat megeloózố kampányidốszakból igyekszik rekonstruálni az internetes tömegkommunikáció politikai napirendjét. A felsorakoztatott elméletek az online tömegkommunikáció egy-egy szegmensére vonatkoznak: a Jankowski és Selm szerzőpáros az internet hozzáadott értékét, Rash a newes management internetre ültetését, Singler és Landler az újságírói szerepek változását, Mensing pedig az internetes politikai napirend alakulását elemzi. A könyv szelleméhez illeszkedik ez a fejezet is, hiszen a felsorakoztatott szerzók az offline világra érvényes tudományos paradigmák alapján értékelik az online tömegkommunikációt, az internetet inkább eszköznek, mintsem radikális változások kiindulópontjának tekintve.

A szerzố maga is elfogadja ezt az álláspontot, és a magyar internetes politikai agendát vizsgálva azt az elófeltevést igyekszik igazolni, miszerint az online tömegkommunikációs médiumoknak a politikai napirendet alakító képessége a politikai pártokéhoz és a hagyományos sajtótermékekéhez képest csekély.

\section{Kiss Balázs - Boda Zsolt: E-aktivizmus, Állampolgárok a neten}

A kötet két zárófejezetét együtt kívánom bemutatni, hiszen maguk a szerzók is azonos vezérfonal mentén építik fel tanulmányaikat. Mindkettő arra a felfogásra épül, hogy az internet politikai szerepe a globális civil társadalomban, az új tevékenységi területek létrehozásában érhetố igazán tetten, a korábban kisebb politikai befolyással bíró szereplók jelentôségének felerôsítésében tapintható ki.

A civilszervezetek és az internet kapcsolatát boncolgató fejezet központi állítása az, hogy a globális civil társadalom egyre nagyobbá váló politikai súlya elképzelhetetlen lenne az internet nélkül, ami tulajdonképpen a civilszervezetek információs politikájának és kommunikációjának köszönhetô. E felfogás elméleti megalapozását Jonathan Bach és David Stark izgalmas koevolúciós megközelítésének interpretációja adja, miszerint az online világ és a civilek globális társadalma az információs társadalom kínálta keretrendszerben sajátos kölcsönhatások eredményeképpen formálja egymást. Ebben a megközelítésben a civilszervezetek tulajdonképpen információbrókerek, akik az állampolgárok és az állami, illetve az üzleti szektor között töltenek be közvetítô szerepet. Létérdekük az, hogy fenntartsák „az információ termelối és fogyasztói közötti távolságot”. Abban az esetben azonban, amikor tudásbrókeri szerepkörbe lépnek, a távolság csökkentésében és mélyreható társadalmi változások implikálásában lesznek érdekeltek. Az elmélet tesztelését ezúttal a hazai zöldszervezetek interneten keresztül végzett mozgalmi tevékenységének feltérképezése jelenti: a szerzók Warkentin tipológiáját felhasználva kérdeznek rá a webkikötók funkcióira, azt vizsgálva, hogy a szervezetek aktivistái ténylegesen mire használják az elektronikus kommunikációt. 
Az Állampolgárok a neten címú fejezet az internethasználatnak a közösségre gyakorolt hatására, valamint az online diskurzusok minőségére irányítja a figyelmet. Szerzôi az internet hatásaival a kisközösségek, illetve az állampolgárok viszonylatában foglalkozó elemzéseket - a weberi premisszák alapján - két fóbb irányzatra bontják, az iparosodás (ma: az IKT) közösségromboló hatásait hangsúlyozó európai iskolát megkülönböztetve az információs és kommunikációs technológiák elterjedéséból a társadalmi tóke növekedését deriváló amerikai - elsôsorban Robert Putnam által képviselt - irányzattól. A közügyek intézésében az interneten keresztül megvalósuló állampolgári részvétel kérdéseit a szerzók elméleti síkon a bináris logika alapján, a „globális falu” és a „Balkán" dichotómiájára redukálva vizsgálják.

Az elmélet igazolásaként az internetes politikai csevegốszobák, fórumok és „topikok" témakörében végzett kutatásokat ismertetik, s ezeken keresztül érzékeltetik egy sajátos körforgás kirajzolódását is: a 90-es évek kutatói Hill-Huges, valamint Schneider nyomán optimista képet festettek a helyzetról és a politikai témák iránt növekvố érdeklődést prognosztizáltak. Az évtized végére azonban Davis, Wilhelm és Bentivegna kutatásai nyomán a szakirodalom pesszimista fordulatot vett, és az állampolgárok internetes jelenlétével foglalkozó tanulmányok csak az új évezred elsô évtizedének közepére, Papacharissi kutatásainak hatására lettek ismét derúlátóbbak. A nemzetközi színtéren végzett vizsgálatok hazai „ellenpróbáját” a 2002. évi választási kampány idején múködött magyar fórumok és „topikok” elemzésével mutatják be a szerzók.

A tanulmánykötet zárógondolata szerint az elektronikus kommunikáció mint az információk közlésének, cseréjének és visszacsatolásának folyamata átalakítja a politikai valóságot. Az internet politikai hasznossága tehát a pluralizálódás és a képviseleti intézményeket ért kihívás, a demokratikus deficit oldaláról érhetố tetten, amit a szerzók a vegyes politika (mixed polity) fogalmával írnak le.

\section{Összegzés}

A kötet az institucionalizmus módszertani kánonjának kétségtelenül eleget tesz, de kérdéses, hogy a politika világa vajon mennyiben mutatható be ennek segítségével. A politikai viszonyok értelmezéséhez elengedhetetlen az emberek társadalmi kapcsolatainak értelmezése, ami a politika és az internet viszonyának elemzéséhez nélkülözhetetlenné teszi a politikai szimbolizmus és a politikai szemantika bevonását az értelmezésbe.

A témát a szerzók kizárólag egyetlen tengely, a technofil-technofób dichotómia mentén tárgyalják. Hiányérzetünk orvoslására Z. Karvalics László Bevezetố az információs társadalom tudománytörténetéhez ${ }^{2}$ címú írását hívhatjuk segítségül. Az ebben a tanulmányban bemutatott többdimenziós térképek szélesebb alapokra helyezett elméleti keretet kínálnak a politika és az internet viszonyának tanulmányozásához. Négy tengely, nevezetesen a dramaturgiai, a rendszerméreti, az axiológiai és a technológiai ten-

${ }^{2}$ Z. Karvalics László (2001): Bevezető az információs társadalom tudománytörténetéhez. Információs Társadalom, 1. szám, 34-48. 
gely mentén egyaránt vizsgálódhatunk. A dramaturgiai tengely mentén a történeti beágyazottságú, a jelenállapot változásait figyelő, valamint a jövőállapotot elôre jelezni kívánó szakirodalom tekinthetô át. A rendszerméretre figyelve a lokálistól egészen a globális szintig vehetjük górcső alá a fennálló társadalmi alakzatokat, az axiológiai metszet az összetett értékkonfliktusok megjelenítését teszi lehetôvé és az értékvilágok újrarétegeződését indítja el, a technológiai tengely mentén pedig az eszközök újabb generációi, valamint az értékhozzáadott mozzanatok, továbbá a technológia társadalmi meghatározottsága is bevonható az elemzésbe.

Recenziómat a kötetben megválaszolatlanul hagyott, de a politika és az internet kapcsolatának szempontjából általam alapvetốen fontosnak és megkerülhetetlennek tekintett kérdések pusztán jelzésszerú felvetésével zárom. Véleményem szerint egy olyan tanulmánykötetnek, amely „a politika és az internet” témakörében készül, az alábbi kérdéseket is meg kell válaszolnia: Miként változtatja meg az internet a nyilvánosság szerkezetét, a cenzúrát? Valóban erôsíti-e a demokráciát a kölcsönös összekapcsoltság, az interkonnektivitás? Mit jelenthet a „digitális választás”? Van-e jövôje, milyen változásokat indukálhat? Mit jelent az információs hadviselés fogalma? Átveheti-e a hagyományos háborúk helyét a kiberhadviselés? Sérülhet-e az állampolgárok önrendelkezési joga a személyes információk (a privacy) tekintetében? Megszüntethetik-e a teleházak a központoktól (és egymástól is) elszigetelt falvak kommunikációs, információs kirekesztettségét? Megszűnhet-e az elektronikus kommunikáció hatására a centrum és a periféria közötti különbség, lehetséges-e, hogy a kizártak is az információs körforgás részeivé váljanak? 